\title{
Phylogenetic relationship of Ornithobacterium rhinotracheale isolated from poultry and diverse avian hosts based on 16S rRNA and rpoB gene analyses
}

Inês M. B. Veiga ${ }^{1,2 \dagger}$, Dörte Lüschow², Stefanie Gutzer ${ }^{2}$, Hafez M. Hafez ${ }^{2}$ and Kristin Mühldorfer ${ }^{3^{* \dagger}}$ (I)

\begin{abstract}
Background: Ornithobacterium (O.) rhinotracheale is an emerging bacterial pathogen in poultry and not fully understood to date. Because of its importance particularly for the global turkey meat industry, reliable diagnostic and characterization methods are needed for early treatment and in future for better vaccine production. The host range of birds infected by $O$. rhinotracheale or carrying the bacterium in their respiratory tract has constantly increased raising important epidemiological and taxonomic questions for a better understanding of its diversity, ecology and transmission cycles. The purpose of this study was to introduce partial rpoB gene sequencing for 0 . rhinotracheale into routine diagnostics to differentiate strains isolated from poultry and more diverse avian hosts (i.e., birds of prey, corvids and pigeons) and to compare phylogenetic relationships with results from $16 \mathrm{~S}$ rRNA gene analysis and multilocus sequence typing (MLST).

Results: Partial 16S rRNA gene analysis revealed a high level of homogeneity among the 65 investigated 0. rhinotracheale sequences with similarity values ranging from 98.6 to $100 \%$ between sequences from non-galliform and poultry species. The corresponding $r p o B$ gene sequences were heterogeneous and ranged in their similarity values from 85.1 to $100 \%$. The structure of the rpoB tree was in strong correlation with previous MLST results revealing three main clusters A (poultry and birds of prey), B (poultry, birds of prey and corvids) and C (pigeons), which were clearly separated from each other.

Conclusions: By using partial sequences from a single gene, the rpoB gene analysis is in good agreement with MLST results with a slight decrease in resolution to distinguish more similar strains. The present results provide strong evidence that traditional phenotypic and genetic methods may not properly represent the heterogeneous group of bacteria classified as $\mathrm{O}$. rhinotracheale. From housekeeping gene analyses, it is very likely that the genus Ornithobacterium includes additional species and partial rpoB gene sequencing can be recommended as fast, costeffective and readily available method to identify strains and differentiate between $O$. rhinotracheale and Ornithobacterium-like bacteria.
\end{abstract}

Keywords: Bacteria, Flavobacteriaceae, Ornithobacterium, ORT, Phylogeny, Birds, Diagnostics, PCR

\footnotetext{
* Correspondence: muehldorfer@izw-berlin.de

†Inês M. B. Veiga and Kristin Mühldorfer contributed equally to this work.

${ }^{3}$ Department of Wildlife Diseases, Leibniz Institute for Zoo and Wildlife

Research, Berlin, Germany

Full list of author information is available at the end of the article
}

(c) The Author(s). 2019 Open Access This article is distributed under the terms of the Creative Commons Attribution 4.0 International License (http://creativecommons.org/licenses/by/4.0/), which permits unrestricted use, distribution, and reproduction in any medium, provided you give appropriate credit to the original author(s) and the source, provide a link to the Creative Commons license, and indicate if changes were made. The Creative Commons Public Domain Dedication waiver (http://creativecommons.org/publicdomain/zero/1.0/) applies to the data made available in this article, unless otherwise stated. 


\section{Background}

Ornithobacterium (O.) rhinotracheale is a relatively novel, emerging bacterial pathogen in turkeys and chickens that causes high economic losses to the commercial poultry production. It was first recognized and taxonomically classified in the early 1990's [1, 2] and has been isolated from poultry flocks worldwide $[3,4]$.

The genus Ornithobacterium belongs to the family of the Flavobacteriaceae [5], which - besides others - also includes the genus Riemerella with $R$. anatipestifer [6, 7] and the genus Coenonia with $C$. anatina [8]. Both bacterial species are also important poultry pathogens mainly of domestic ducks and geese. Besides a new species proposed as Candidatus Ornithobacterium hominis sp. nov. [9], O. rhinotracheale is the only bacterial species described within the genus Ornithobacterium but not fully understood to date. Because of its veterinary importance particularly for the global turkey meat industry [10] the need for reliable diagnostic and characterization methods is obvious for early treatment. Its cultural characteristics and fastidious requirements (i.e., small colony size, slow growth, enriched media and capnophilic incubation), however, may challenge bacterial isolations and reduce the detection rates $[11,12]$. Therefore, molecular detection of $O$. rhinotracheale DNA from tissues or swabs targeting the $16 \mathrm{~S}$ rRNA gene with specific primers is frequently used in routine diagnostics, but $16 \mathrm{~S}$ sequences often lack the resolution to capture heterogeneity among the strains [13-15].

Over the past few decades, the host range of birds infected by $O$. rhinotracheale or carrying the bacterium in their respiratory tract has constantly increased [16]. The presence of $O$. rhinotracheale in apparently healthy, captive and free-ranging non-galliform species raises important epidemiological and taxonomic questions for a better understanding of its diversity, ecology and transmission cycles. Multilocus sequence typing (MLST) recently established by Thieme et al. [3, 16] not only revealed specific phylogenetic relationships in non-galliform birds such as pigeons and birds of prey, but also identified few strains from turkeys and chickens that clearly differed from the main poultry cluster. The aim of the present study was to introduce partial rpoB gene sequencing for $O$. rhinotracheale into routine diagnostics to differentiate strains isolated from poultry and more diverse avian hosts and to compare the results with those from 16S rRNA gene and MLST analyses. The rpoB gene has been proved very useful and powerful for bacterial identification and phylogenetic studies [17-19].

\section{Methods}

\section{Bacterial strains}

Sixty-five strains previously identified as O. rhinotracheale were used for genetic analyses (Table 1), including 51 strains that were already investigated by MLST and represent the 31 sequence types (ST) as described by Thieme et al. [3, 16], and six additional strains isolated from turkeys in Portugal (present study). Eight strains were identified only genetically from swab samples of different birds of prey and corvid species [20]. They were included in the $r p o B$ gene analysis to investigate mixed bacterial DNA samples, when $O$. rhinotracheale cannot be obtained from bacterial cultures because of its fastidious growth requirements and concomitant fast-growing bacteria.

\section{S rRNA and $r p o B$ gene analyses}

Amplification of the O. rhinotracheale specific $16 \mathrm{~S}$ rRNA gene fragment (784 bp) was performed according to Numee et al. [14] with primer sequences described by van Empel and Hafez [11]. The rpoB gene fragment (538 bp) was amplified using $1 \mu \mathrm{M}$ of primers rpoBFla-f (5'-TCAATTCGTTCTTTGGAAC- 3') and rpoBFla-r (5'-GCATCATGTTAGATCCCAT-3') with cycling conditions as follows: $3 \mathrm{~min}$ denaturation at $94{ }^{\circ} \mathrm{C}$, followed by 30 cycles at $94^{\circ} \mathrm{C}$ for $30 \mathrm{~s}, 54^{\circ} \mathrm{C}$ for $30 \mathrm{~s}$ and $72^{\circ} \mathrm{C}$ for $45 \mathrm{~s}$, and a final extension step at $72{ }^{\circ} \mathrm{C}$ for $5 \mathrm{~min}$. rpoB primers were designed based on published genomic sequences within the family Flavobacteriaceae (including Riemerella strains NCTC $11014^{\mathrm{T}}$ and LMG $11607^{\mathrm{T}}$, and O. rhinotracheale strain DSM $15997^{\mathrm{T}}$ ) as described by Christensen and Bisgaard [19]. 16S rRNA and rpoB PCR products were gel purified (MinElute Gel Extraction Kit, Qiagen, Hilden, Germany) and Sanger sequenced in both directions at LGC Genomics, Berlin, Germany, using PeakTrace $^{\mathrm{Tm}}$ Basecaller and the PHRED 20 quality score. The identity of bacterial species was confirmed using BLAST search against the GenBank database.

Phylogenetic analyses of partial 16S rRNA (632 bp) and $\mathrm{rpoB}(538 \mathrm{bp})$ gene sequences were performed with MEGA6 [21] by using the Maximum Likelihood method based on the Jukes-Cantor model [22]. As several O. rhinotracheale strains were identical in their partial $16 \mathrm{~S}$ rRNA and $r p o B$ gene sequences, phylogenetic trees were built for 47 out of 65 strains and Riemerella anatipestifer DSM $15868^{\mathrm{T}}$ (accession number NC_017045) was included as outgroup. The O. rhinotracheale type strain DSM $15997^{\mathrm{T}}$ (accession number NC_018016) was included for sequence similarity comparisons (Table 2).

\section{Results and discussion}

Within the 16S rRNA gene analysis, the 65 O. rhinotracheale specific partial sequences showed a high level of homogeneity with similarity values ranging from 98.6 and $98.7 \%$ (ten strains from pigeons, GV37 and GV38) to $100 \%$ (strains from turkey or chicken and GV1) between non-galliform and poultry species. The structure of the phylogenetic tree (Fig. 1), however, was largely comparable to MLST results [16]. The majority of $O$. rhinotracheale strains were arranged in one cluster and separated from two subsets of three strains each isolated 
Table 1 Ornithobacterium rhinotracheale strains used for $16 \mathrm{~S}$ rRNA and rpob gene analyses

\begin{tabular}{|c|c|c|c|c|}
\hline Strain ID & Host & Bird family & MLST & Reference \\
\hline RefA, RefE, GB 1707/12/2, GB 1707/12/3 & Chicken & Phasianidae & ST1 & [3], present study \\
\hline RefB, Refl, RefM, RefP, GB 1312/05/2 & Turkey & Phasianidae & ST1 & {$[3]$, present study } \\
\hline RefC & Chicken & Phasianidae & ST2 & {$[3]$, present study } \\
\hline RefD, RefH & Turkey & Phasianidae & ST3 & {$[3]$, present study } \\
\hline RefQ & Chicken & Phasianidae & ST3 & {$[3]$, present study } \\
\hline GK 1112/96 & Pheasant & Phasianidae & ST3 & {$[3]$, present study } \\
\hline RefF & Turkey & Phasianidae & ST4 & {$[3]$, present study } \\
\hline RefG & Chicken & Phasianidae & ST5 & {$[3]$, present study } \\
\hline RefJ, RefK & Chicken & Phasianidae & ST6 & {$[3]$, present study } \\
\hline RefL & Turkey & Phasianidae & ST6 & {$[3]$, present study } \\
\hline RefN & Guinea fowl & Numididae & ST7 & {$[3]$, present study } \\
\hline RefO & Rook & Corvidae & ST8 & [3], present study \\
\hline GB 1312/05/22, GB 371/09/5, GB 804/13/1 & Turkey & Phasianidae & ST9 & {$[3]$, present study } \\
\hline GB 137/10/2 & Chicken & Phasianidae & ST10 & {$[3]$, present study } \\
\hline GB 738/10/1, GB 738/10/3 & Turkey & Phasianidae & ST11 & [3], present study \\
\hline GB 1573/11/17 & Turkey & Phasianidae & ST12 & {$[3]$, present study } \\
\hline GB 2399/13 & Chicken & Phasianidae & ST13 & {$[3]$, present study } \\
\hline GB 978/14/1 & Turkey & Phasianidae & ST14 & {$[3]$, present study } \\
\hline GV1 & Turkey vulture & Cathartidae & ST15 & {$[3,20]$, present study } \\
\hline GV6 & Harris's hawk & Accipitridae & ST16 & {$[3,20]$, present study } \\
\hline GV13 & Red kite & Accipitridae & ST16 & {$[3,20]$, present study } \\
\hline GV9 & Common kestrel & Falconidae & ST17 & {$[3,20]$, present study } \\
\hline GV10 & Peregrine falcon & Falconidae & ST18 & {$[3,20]$, present study } \\
\hline GV11 & Saker falcon & Falconidae & ST18 & {$[3,20]$, present study } \\
\hline GV12 & Saker-gyrfalcon & Falconidae & ST18 & {$[3,20]$, present study } \\
\hline GV143 & Common kestrel & Falconidae & ST19 & {$[3,20]$, present study } \\
\hline GV149 & Common kestrel & Falconidae & ST20 & {$[3,20]$, present study } \\
\hline T85 & Pigeon & Columbidae & ST21 & {$[16]$, present study } \\
\hline T49 & Pigeon & Columbidae & ST22 & [16], present study \\
\hline T97 & Pigeon & Columbidae & ST23 & {$[16]$, present study } \\
\hline T91 & Pigeon & Columbidae & ST24 & {$[16]$, present study } \\
\hline T37 & Pigeon & Columbidae & ST25 & {$[16]$, present study } \\
\hline T66, T143 & Pigeon & Columbidae & ST26 & {$[16]$, present study } \\
\hline T52 & Pigeon & Columbidae & ST27 & [16], present study \\
\hline T92 & Pigeon & Columbidae & ST28 & {$[16]$, present study } \\
\hline T102 & Pigeon & Columbidae & ST29 & [16], present study \\
\hline T203 & Pigeon & Columbidae & ST30 & [16], present study \\
\hline $165-2 / 2015$ & Common buzzard & Accipitridae & ST31 & [16], present study \\
\hline $\mathrm{GV} 22^{\mathrm{a}}$ & Northern goshawk & Accipitridae & n.d. & [20], present study \\
\hline $\mathrm{GV} 37^{\mathrm{a}}$ & White-tailed eagle & Accipitridae & n.d. & [20], present study \\
\hline GV3 $38^{\mathrm{a}}$ & Osprey & Accipitridae & n.d. & [20], present study \\
\hline $\mathrm{GV} 55^{\mathrm{a}}$ & Common kestrel & Falconidae & n.d. & [20], present study \\
\hline $\mathrm{R} 68^{\mathrm{a}}$ & Carrion crow & Corvidae & n.d. & [20], present study \\
\hline $\mathrm{R} 70^{\mathrm{a}}$ & Eurasian magpie & Corvidae & n.d. & [20], present study \\
\hline
\end{tabular}


Table 1 Ornithobacterium rhinotracheale strains used for 16S rRNA and rpob gene analyses (Continued)

\begin{tabular}{lllll}
\hline Strain ID & Host & Bird family & MLST & Reference \\
\hline GV82 $^{a}$ & Common buzzard & Accipitridae & n.d. & [20], present study \\
GV89 & Sparrow hawk & Accipitridae & n.d. & [20], present study \\
PTCV-ORT-Mist, PTCV731, PTCV1320, & Turkey & Phasianidae & n.d. & present study \\
PTCV1556, PTCV1714, PTCV2283 & & & \\
\hline
\end{tabular}

MLST Multilocus sequence typing, ST Sequence type, n.d. Not determined

${ }^{a}$ swab sample

from poultry (family Phasianidae) or birds of prey (family Accipitridae), respectively. One of the O. rhinotracheale serotype reference strains (RefF) belonged to the aforementioned subset of the three strains from poultry (including GB 978/14/1 and GB 137/10/2) and formed a separate cluster in previous studies too $[14,15]$.

The main $16 \mathrm{~S}$ cluster was split into two subclusters with 47 strains collected from poultry, birds of prey and corvids, which are more closely related to each other and comprise a high diversity of bird families and species. In contrast, the second subcluster only involved 11 strains from pigeons and one strain from a white-tailed eagle (GV37, family Accipitridae). The latter grouped together with two strains isolated from feral pigeons, which were separated from strains collected from pigeons of a pigeon loft [16].

The 65 partial $r p o B$ gene sequences were heterogeneous and ranged in their similarity values from 85.1 to $100 \%$. The structure of the phylogenetic tree was in strong correlation with MLST results [16]. Three distinct clusters A $(n=6$; poultry and birds of prey), B ( $n=47$; poultry, birds of prey and corvids) and C ( $n=11$; only pigeon) were identified (Fig. 2 ) that corresponded well to the MLST clusters [16]. Strain GV37 formed a distinct lineage and only shared 86.2 to $87.4 \%$ sequence similarity with strains of cluster A, 86.8 to $87.5 \%$ similarity with strains of cluster B and 85.1 to $85.5 \%$ similarity with strains of cluster C (Table 2). Within cluster A, three strains from turkeys and chicken (98.7 to $100 \%$ similarity) were clearly separated from three strains collected from birds of prey $(99.4$ to $100 \%$ similarity). Both groups shared only 94.2 to $94.8 \%$ sequence similarity. In contrast, $r p o B$ gene sequence similarity values among strains from cluster B or cluster C ranged from 98.5 and $98.0 \%$ to $100 \%$, respectively.

Sequence analysis of a specific $r p o B$ gene fragment is widely used in addition to the $16 \mathrm{~S}$ rRNA gene for more reliable bacterial identification and taxonomic classifications at genus and species level [17]. For members of the family Pasteurellaceae, rpoB similarity cut-offs of 85 and $95 \%$ were recommended for the description of new genera and species, respectively [23]. For the family Flavobacteriaceae, corresponding similarity cut-offs have not been defined so far [24]. Partial rpoB gene analyses, however, proved to be very useful to reveal clear phylogenetic relationships of Riemerella strains and related members of Flavobacteriaceae [19]. Likewise, O. rhinotracheale strains from this study show strong differences in similarity among their $r p o B$ gene sequences. Strains of cluster $A$ and cluster $C$ as well as strain GV37 were clearly separated from cluster $B$, a genetically homogenous group that includes the majority of $O$. rhinotracheale strains and the O. rhinotracheale type strain DSM $15997^{\mathrm{T}}$. Moreover, comparisons with O. rhinotracheale DSM $15997^{\mathrm{T}}$ or respective with strains from cluster B revealed sequence similarities of $\leq 90.0 \%$ but above $85.0 \%$ (Table 2), which would only support bacterial identification at genus level.

\section{Conclusions}

By using partial sequences from a single gene, the $r p o B$ gene analysis is in good agreement with MLST results with a slight decrease in resolution to distinguish more similar strains. Eight rpoB gene sequences were received from swab samples (all non-galliform birds) [20] extending the avian host

Table 2 rpoB gene sequence similarity values of phylogenetic clusters in comparison and with type strain Ornithobacterium rhinotracheale DSM $15997^{\top}$

\begin{tabular}{lllll}
\hline rpoB gene sequences & Cluster A & Cluster B & Cluster C & Strain GV37 \\
\hline Cluster A & 94.2 to $100 \%$ & 87.4 to $89.0 \%$ & 85.3 to $87.0 \%$ & 86.2 to $87.4 \%$ \\
Cluster B & 87.4 to $89.0 \%$ & 98.5 to $100 \%$ & 88.5 to $90.0 \%$ & 86.8 to $87.5 \%$ \\
Cluster C & 85.3 to $87.0 \%$ & 88.5 to $90.0 \%$ & 98.0 to $100 \%$ & 85.1 to $85.5 \%$ \\
Strain GV37 & 86.2 to $87.4 \%$ & 86.8 to $87.5 \%$ & 85.1 to $85.5 \%$ & 88.9 to $89.2 \%$ \\
\hline
\end{tabular}




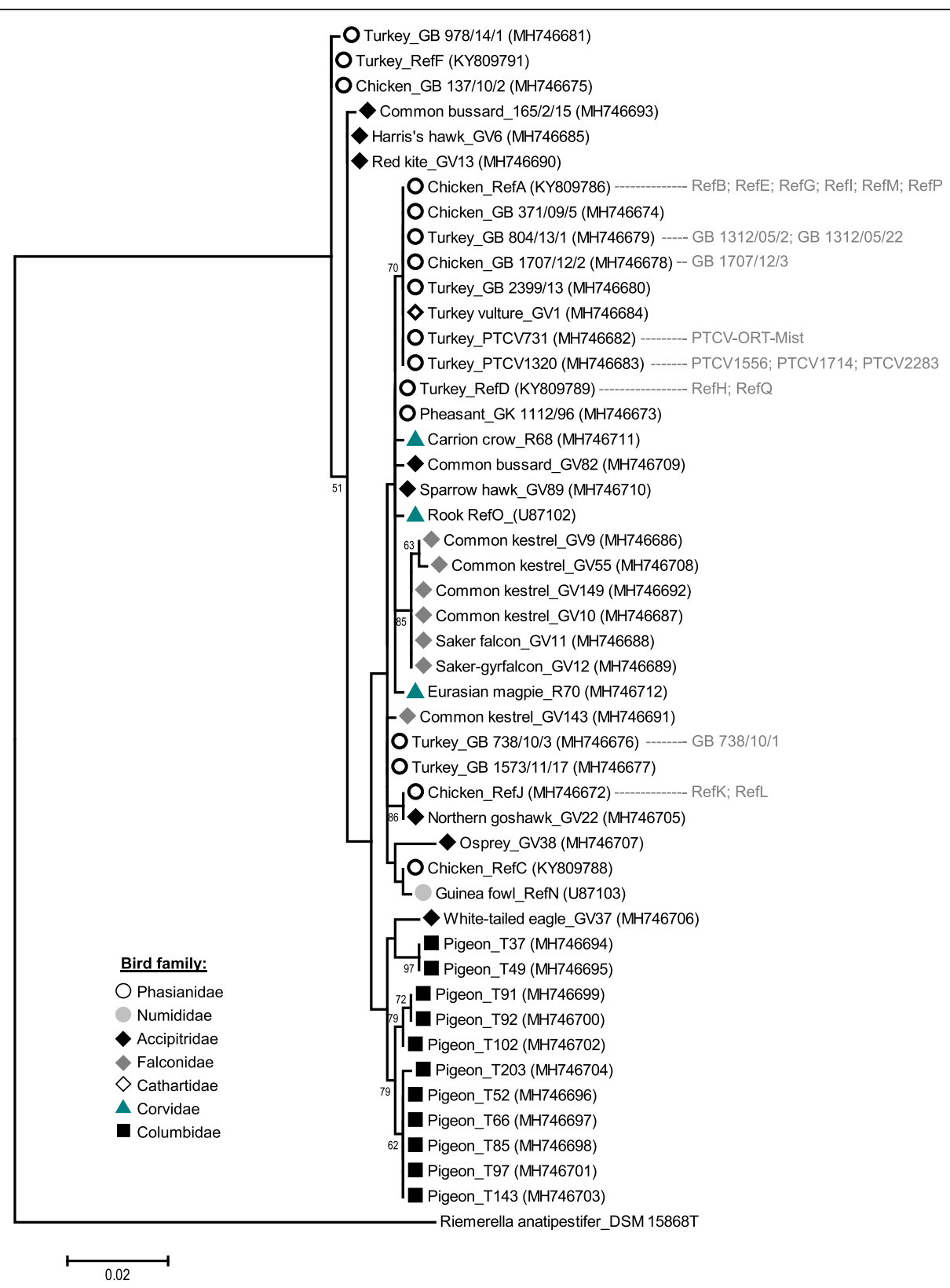

Fig. 1 Phylogenetic tree based on partial 16S rRNA gene sequences ( $632 \mathrm{bp}$ ) and constructed in MEGA6 [21] by using the Maximum Likelihood method based on the Jukes-Cantor model [22]. The tree was built with 47 out of $65 \mathrm{O}$. rhinotracheale sequences (remaining identical sequences are indicated in grey) and Riemerella anatipestifer DSM $15868^{\top}$ (NC_017045) as outgroup. GenBank accession numbers are given in brackets. The percentage of replicate trees (> 50\%) in which the associated taxa clustered together in the bootstrap analysis (100 replicates) is shown next to the branches. Initial tree(s) for the heuristic search were obtained by applying the Neighbor-Joining method to a matrix of pairwise distances estimated using the Maximum Composite Likelihood (MCL) approach. The tree is drawn to scale, with branch lengths measured in the number of substitutions per site

range and phylogenetic relationships investigated by MLST. On a bird family-level, the Columbidae specific cluster $\mathrm{C}$ and two different subclusters of three strains from Accipitridae species (namely 165-2/ 2015, GV8 and GV13) and seven strains from Falconidae species (namely GV9 to GV12, GV55, GV143 and GV149) were seen likewise to MLST [16]. At the same time, however, several $O$. rhinotracheale strains from different poultry species, birds of prey and corvid species have a close genetic relationship (similarity $298.5 \%$ ) pointing towards the risk of interspecies transmission. Moreover, our results 


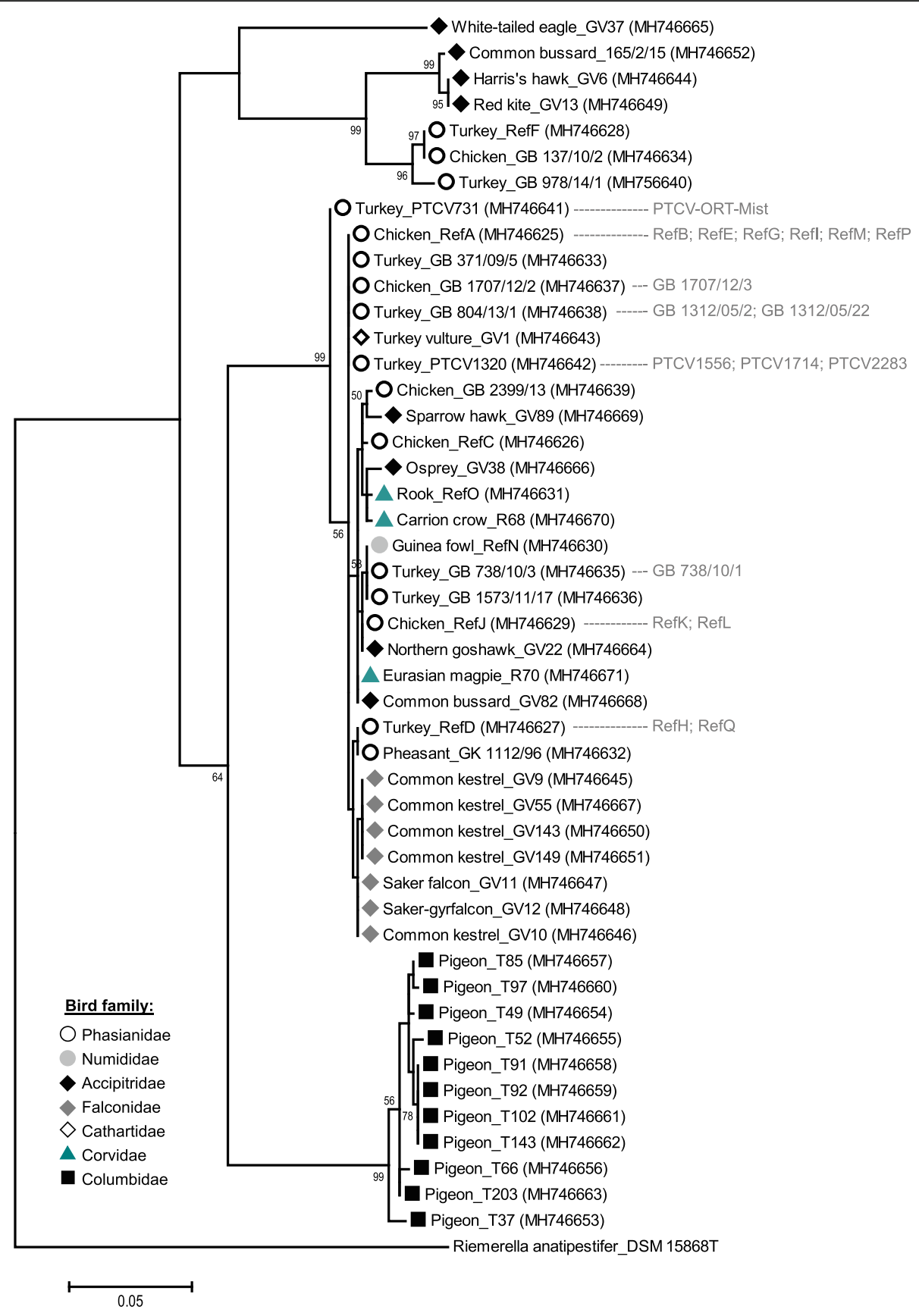

Fig. 2 Phylogenetic tree based on partial rpoB gene sequences (538 bp) and constructed in MEGA6 [21] by using the Maximum Likelihood method based on the Jukes-Cantor model [22]. The tree was built with 47 out of $65 \mathrm{O}$. rhinotracheale sequences (remaining identical sequences are indicated in grey) and Riemerella anatipestifer DSM $15868^{\top}$ (NC_017045) as outgroup. GenBank accession numbers are given in brackets. The percentage of replicate trees $(>50 \%)$ in which the associated taxa clustered together in the bootstrap analysis (100 replicates) is shown next to the branches. Initial tree(s) for the heuristic search were obtained by applying the Neighbor-Joining method to a matrix of pairwise distances estimated using the Maximum Composite Likelihood (MCL) approach. The tree is drawn to scale, with branch lengths measured in the number of substitutions per site

provide strong evidence that traditional phenotypic and genetic methods used for identification may not properly represent the heterogeneous group of bacteria classified as $O$. rhinotracheale. From housekeeping gene analyses, it is very likely that the genus
Ornithobacterium includes additional species and partial $r р о B$ gene sequencing can be recommended as fast, cost-effective and readily available method to identify strains and differentiate between $O$. rhinotracheale and Ornithobacterium-like bacteria. 


\section{Abbreviations}

MLST: Multilocus sequence typing; PCR: Polymerase chain reaction; ST: Sequence type

\section{Acknowledgements}

The authors would like to thank Elke Dyrks and Gabriele Grotehenn for their excellent technical assistance, and Dr. Ana Martins from ALS Controlvet Portugal and Dr. Rita Silva from Desenvolvimento e Inovacão industrial Lda (DIN) for providing six O. rhinotracheale strains from turkeys in Portugal.

\section{Funding}

IMBV was funded by a postdoctoral Honors Fellowship 2013-2 from the Dahlem Research School (DRS), Freie Universität Berlin, Germany. The funding body had no role in any aspect of this study.

The publication of this article was funded in part by the Open Access Fund of the Leibniz Association.

\section{Availability of data and materials}

Newly obtained sequences of the different genes from the 47 representative strains used for phylogenetic analyses have been deposited in GenBank (www.ncbi.nlm.nih.gov/genbank) and are available under their accession numbers (16S rRNA accession numbers: MH746672 to MH746712; rpoB accession numbers: MH746625 to MH746671). 16S rRNA gene sequences of strains RefA to RefH, RefO and RefN are available under accession numbers KY809786 to KY809793 [15], U87102 and U87103 [13], respectively.

\section{Authors' contributions}

IMBV and KM conceived and designed the experiments; IMBV, SG, DL performed the experiments; IMBV, SG, DL, HMH, KM contributed isolates/ reagents/materials/analysis tools; $\mathrm{KM}$ analyzed the data and wrote the paper. All authors read and approved the final manuscript.

\section{Ethics approval and consent to participate}

Samples and bacterial isolates used in the present study were obtained for diagnostic purposes and do not require ethical approval or owner consent.

\section{Consent for publication}

Not applicable.

\section{Competing interests}

The authors declare that they have no competing interests.

\section{Publisher's Note}

Springer Nature remains neutral with regard to jurisdictional claims in published maps and institutional affiliations.

\section{Author details}

${ }^{1}$ Present Address: Institute of Animal Pathology, Bern, Switzerland. ${ }^{2}$ Institute of Poultry Diseases, Freie Universität Berlin, Berlin, Germany. ${ }^{3}$ Department of Wildlife Diseases, Leibniz Institute for Zoo and Wildlife Research, Berlin, Germany.

Received: 17 August 2018 Accepted: 16 January 2019 Published online: 06 February 2019

\section{References}

1. Hafez HM, Kruse W, Emele J, Sting R. Eine Atemwegsinfektion bei Mastputen durch Pasteurella-ähnliche Erreger: Klinik, Diagnostik und Therapie. In: Proceedings of the international conference on poultry diseases. Potsdam: German Veterinary Medical Society (DVG); 1993. p. 105-12.

2. Vandamme $P$, Segers $P$, Vancanneyt $M$, van Hove $K$, Mutters $R$, Hommez J, et al. Ornithobacterium rhinotracheale gen. Nov., sp. nov., isolated from the avian respiratory tract. Int J Syst Bacteriol. 1994;44:24-37.

3. Thieme S, Mühldorfer K, Gad W, Lüschow D, Hafez MH. Molecular characterization of the recently emerged poultry pathogen Ornithobacterium rhinotracheale by multilocus sequence typing. PLoS One. 2016;11:e0148158.

4. Ha HJ, Christensen N, Humphrey S, Haydon T, Bernardi G, Rawdon T. The first detection of Ornithobacterium rhinotracheale in New Zealand. Avian Dis. 2016;60:856-9.
5. Hafez HM, Vandamme P, Ornithobacterium Vandamme GXXVI. Segers, Vancanneyt, Van Hove, Mutters, Hommez, Dewhirst, Paster, Kersters, Falsen, Devriese, Bisgaard, Hinz and Mannheim 1994, 35 VP. In: Krieg NR, Stanley JT, Brown DR, Hedlund BJ, Paster NL, et al., editors. Bergey's manual of systematic bacteriology. 2nd ed. New York: Springer; 2011. p. 250-314.

6. Segers P, Mannheim W, Vancanneyt M, De Brandt K, Hinz KH, Kersters K, et al. Riemerella anatipestifer gen. Nov., comb. nov., the causative agent of septicaemia anserum exsudativa, and its phylogentic affiliation within the Flavobacterium-Cytophaga rRNA homology group. Int J Syst Evol Microbiol. 1993:43:768-76.

7. Rubbenstroth D, Ryll M, Hotzel H, Christensen H, Knobloch JK-M, Rautenschlein $\mathrm{S}$, et al. Description of Riemerella columbipharyngitis sp. nov., isolated from the pharynx of healthy domestic pigeons (Columba livia f. domestica), and emended descriptions of the genus Riemerella, Riemerella anatipestifer and Riemerella columbina. Int J Syst Evol Microbiol. 2013;63:280-7.

8. Vandamme $P$, Vancanneyt $M$, Segers $P$, Ryll M, Köhler B, Ludwig W, et al. Coenonia anatina gen. Nov., sp. nov., a novel bacterium associated with respiratory disease in ducks and geese. Int J Syst Bacteriol. 1999;49:867-74.

9. Salter SJ, Scott P, Page AJ, Tracey A, de Goffau MC, Ochoa-Montano B, et al. Candidatus Ornithobacterium hominis sp. nov.: insights gained from draft genomes obtained from nasopharyngeal swabs. bioRxiv. preprint. 2018. https://doi.org/10.1101/326074

10. Sprenger SJ, Halvorson DA, Shaw DA, Nagaraja KV. Ornithobacterium rhinotracheale infection in turkeys: immunoprophylaxis studies. Avian Dis. 2000;44:549-55.

11. Van Empel PCM, Hafez MH. Ornithobacterium rhinotracheale: a review. Avian Pathol. 1999:28:217-27.

12. Zahra M, Ferreri M, Alkasir R, Yin J, Han B, Isolation SJ. Characterization of small-colony variants of Ornithobacterium rhinotracheale. J Appl Microbiol. 2013;51:3228-36.

13. Amonsin A, Wellehan JFX, Li L-L, Vandamme P, Lindeman C, Edman M, et al. Molecular epidemiology of Ornithobacterium rhinotracheale. J Clin Microbiol. 1997;35:2894-8.

14. Numee S, Hauck R, Hafez HM. Detection and typing of Ornithobacterium rhinotracheale from German poultry flocks. Avian Dis. 2012;56:654-8.

15. Montes de Oca-Jimenez R, Vega-Sanchez V, Morales-Erasto V, SalgadoMiranda C, Blackall PJ, Soriano-Vargas E. Phylogenetic relationship of Ornithobacterium rhinotracheale strains. J Vet Med Sci. 2018;80:869-73.

16. Thieme S, Hafez MH, Gutzer S, Warkentin N, Lüschow D, Mühldorfer K. Multilocus sequence typing of Ornithobacterium rhinotracheale isolated from pigeons and birds of prey revealed new insights into its population structure. Vet Anim Sci. 2016b;1:15-20.

17. Adékambi T, Drancourt M, Raoult D. The rpoB gene as a tool for clinical microbiologists. Trends Microbiol. 2009;17:37-45.

18. Korczak B, Christensen H, Emler S, Frey J, Kuhnert P. Phylogeny of the family Pasteurellaceae based on $r p o B$ sequences. Int J Syst Evol Microbiol. 2004:54:1939.

19. Christensen H, Bisgaard M. Phylogenetic relationships of Riemerella anatipestifer serovars and related taxa and an evaluation of specific PCR tests reported for R. anatipestifer. J Appl Microbiol. 2009;108:1612-9.

20. Gutzer S, Lüschow D, Hafez HM. Wild birds as source of Ornithobacterium rhinotracheale infections. In: Hafez HM, editor. Proceedings of the 7th "Hafez" international symposium on Turkey production. Meeting of the working group 10 (Turkey) of World's poultry science association. Berlin: Mensch \& Buch Verlag; 2013. p. 193-5.

21. Tamura K, Stecher G, Peterson D, Filipski A, Kumar S. MEGA6: molecular evolutionary genetics analysis version 6.0. Mol Biol and Evol. 2013;30:2725-9.

22. Jukes TH, Cantor CR. Evolution of protein molecules. In: Munro HN, editor. Mammalian Protein Metabolism. New York: Academic Press; 1969. p. 21-132.

23. Christensen H, Kuhnert P, Busse H-J, Frederiksen W, Bisgaard M. Proposed minimal standrads for the description of genera, species and subspecies of the Pasteurellaceae. Int J Syst Evol Microbiol. 2007;57:166-78.

24. Bernardet JF, Nakagawa Y, Holmes B. Subcommittee on the taxonomy of Flavobacterium and Cytophaga-like bacteria of the international committee on systematics of prokaryotes. Proposed minimal standards for describing new taxa of the family Flavobacteriaceae and emended description of the family. Int J Syst Evol Microbiol. 2002;52:1049-70. 